\title{
A Century after! Rediscovery of the ancient catfish Diplomystes Bleeker 1858 (Siluriformes: Diplomystidae) in coastal river basins of Chile and its implications a for conservation
}

Correspondence:

Carlos P. Muñoz-Ramírez carmunoz@umich.edu

Submitted July 26, 2019

Accepted January 15, 2020

by Priscila Camelier

Published April 20, 2020

Online version ISSN 1982-0224

Print version ISSN 1679-6225

Neotrop. Ichthyol.

vol. 18, no. 1, Maringá 2020

Epub, Apr 17, 2020
๑Carlos P. Muñoz-Ramírez ${ }^{1,2}$, $\odot$ Raul Briones ${ }^{3}$, $\odot$ Nicole Colin ${ }^{4}$, -Pablo Fierro5 ${ }^{5}$ ๑Konrad Górski ${ }^{2,5}$, ๑Alfonso Jara ${ }^{6}$ and (๑)Aliro Manosalva ${ }^{6}$

The ancient catfish family Diplomystidae, with seven species endemic to rivers of southern South America, represents one of the oldest branches of the diverse order Siluriformes. With most species endangered, new reports of these species become extremely valuable for conservation. Currently, it is assumed that Diplomystes species inhabit only Andean (large) basins, and that they are extinct from coastal (small) basins from which their presence have not been recorded since 1919. Here, we document new records of the family Diplomystidae in the Laraquete and Carampangue basins, two coastal basins from the Nahuelbuta Coast Range, Chile, with no previous reports. This finding represents the rediscovery of the genus in coastal basins in more than a Century. Based on analysis of mitochondrial DNA sequences, the collected specimens were found to be closely related to Diplomystes nahuelbutaensis from the Andean Biobío Basin, but sufficiently differentiated to suggest that coastal basin populations are a different management unit. These populations are important because, contrary to previous thoughts, they prove these catfish can survive in small river networks, providing unique opportunities for research and conservation. The conservation category of Critically Endangered (CE) is recommended for the populations from the Laraquete and Carampangue basins.

Keywords: Management Unit, Mitochondrial DNA, Rare Species, Streams, Threatened Species.

1 Instituto de Entomología, Facultad de Ciencias Básicas, Universidad Metropolitana de Ciencias de la Educación, Santiago, Chile. carmunoz@umich.edu

2 Centro de Investigación en Biodiversidad y Ambientes Sustentables (CIBAS), Universidad Católica de la Santísima Concepción, Chile. konrad.gorski@uach.cl

3 BIOFOREST-Arauco S. A., Programa de Conservación de Especies, Concepción, Chile. raul.briones@arauco.cl

4 Instituto de Ciencias Ambientales y Evolutivas, Facultad de Ciencias, Universidad Austral, Chile. colin.nicole@gmail.com

5 Instituto de Ciencias Marinas y Limnológicas, Facultad de Ciencias, Universidad Austral de Chile, Valdivia, Chile. pablo.fierro@uach.cl

6 Facultad de Ciencias Ambientales y Centro EULA-Chile, Universidad de Concepción, Concepción, Chile.

(AJ) gaizcka@gmail.com; (AM) aliromanosalva@gmail.com 
La familia de bagres Diplomystidae, con siete especies endémicas de ríos del sur de Sudamérica, es uno de los linajes mas antiguos del diverso orden Siluriformes. Al estar la mayoría de las especies amenazadas, nuevos registros de éstas son extremadamente valiosos para su conservación. Actualmente, se ha asumido que los Diplomystidos se distribuyen solo en cuencas Andinas (más grandes), y que sus especies estarían extintas en cuencas de menor tamaño como las costeras, sin registros desde 1919. En este trabajo documentamos la familia Diplomistidae en las cuencas de Carampangue y Laraquete, dos cuencas costeras de la Cordillera de Nahuelbuta, Chile, lo que representa el primer registro de esta familia en estas cuencas costeras. Además, este hallazgo representa el re-descubrimiento de la familia en cuencas costeras después de un siglo. Sobre la base de análisis de ADN mitocondrial, los especímenes colectados se relacionaron más cercanamente con poblaciones de la especie Diplomystes nahuelbutaensis presente en la cuenca del Biobío. Sin embargo, existen diferencias genéticas suficientes entre las poblaciones costeras y las del Biobío para justificar su separación como unidad de manejo distinta. Estas poblaciones costeras son importantes porque demuestran que los Diplomístidos pueden sobrevivir en cuencas de pequeño tamaño, ofreciendo oportunidades únicas para su investigación y conservación. Se recomienda la categoría de conservación En Peligro Critico de Extinción (CR) para las poblaciones de las cuencas Laraquete y Carampangue.

Palabras clave: ADN Mitocondrial, Especie Amenazada, Especie Rara, Esteros, Unidad de Manejo.

\section{INTRODUCTION}

Conservation of rare, ancient species is fundamental because they contribute disproportionately more to biodiversity (Faith, 1992) and their extinction would cause a severe loss of important branches of the tree of life. The strictly freshwater catfish family Diplomystidae is one of such groups of species. With only seven species, it forms one of the earliest branching groups of the diverse order Siluriformes, with extensive morphological evidence placing Diplomystidae as the sister group of all other catfish worldwide (Lundberg, Baskin, 1969; Arratia, 1987; Grande, 1987; Mo, 1991; de Pinna, 1998; Diogo, 2004; Hardman, 2005). One study, based on two nuclear genes, have placed the suborder Loricarioidei as sister to a group conformed by Diplomystidae and the suborder Siluroidei (Sullivan et al., 2006). Recent work, however, have supported Diplomystidae as the sister group of all other catfish (Rivera-Rivera, Montoya-Burgos, 2018). Unfortunately, and despite the importance of the family for understanding catfish evolution, most species face conservation issues, with three species (Diplomystes chilensis (Molina, 1782), D. nahuelbutaensis Arratia, 1987, and D. camposensis Arratia, 1987) considered Endangered by the Chilean Government (MINSEGPRES, 2008), although one of these (D. chilensis) has been assumed Extinct by some authors (Muñoz-Ramírez et al., 2010, 2014; Arratia, Quezada-Romegialli, 2017). In Argentina, diplomystids 
are insufficiently known (Bello, Ubeda, 1998) and some authors have suggested the maximum conservation priority for Diplomystes mesembrinus (Ringuelet, 1982) (Bello, Ubeda, 1998; López et al., 2002). The International Union for Conservation of Nature (IUCN, 2019) lists only three Diplomystid species (D. chilensis, D. nahuelbutaensis and D. camposensis), all under the Data Deficient (DD) category. Habitat deterioration, the introduction of invasive species, and habitat fragmentation have been invoked as the main causes impacting the conservation of the family (Arratia, 1983; López et al., 2002).

Based on origin, Chilean river networks are divided into Andean and Coastal basins. Andean basins are formed in the Andes Mountain Range and are larger and more complex than coastal basins, with greater number of tributaries and rivers of higher order. Coastal basins are formed in the west flank of the older Chilean Coast Range, closer to the Pacific Ocean and, therefore, formed by smaller river networks. Diplomystids have been documented almost exclusively from rivers of Andean origin from Central and South Chile as well as Argentina. Specimens collected by Eigenmann in 1919 from the Nonguen River (Andalien Basin) near Concepción $\left(36.86^{\circ} \mathrm{S}, 73^{\circ} \mathrm{W}\right.$ ), Chile (material studied in Arratia, 1987), are the only reference of diplomystids from coastal basins. Other surveys in coastal rivers have yielded negative results (e.g., Ruiz, 1993; Habit, Victoriano, 2005; Arratia, Quezada-Romegialli, 2017). The lack of records since then, along with evidence of large home range based on telemetry (Oyanedel et al., 2018), genetics (Muñoz-Ramírez et al., 2014, 2015, 2016), and ecology (Habit et al., 2009) have promoted the idea that diplomystids required relatively large river networks to survive. Conservation plans, although urgent, are therefore challenging as they would require the protection of large and well connected river areas that will soon be threatened by severe fragmentation due to hydropower boom (Díaz et al., 2019).

In this study an unexpected new record of Diplomystes from coastal basins is documented a century after the last collection of specimens in 1919. These populations are located between two Andean basins, Biobío and Imperial, habitat of two distinct lineages of Diplomystes nahuelbutaensis (Muñoz-Ramírez et al., 2014) which suggest these populations belong to this species. Mitochondrial DNA was obtained and molecular phylogenetic analyses conducted to i) estimate the phylogenetic position of these coastal populations within the family Diplomystidae, and ii) evaluate genetic structure with the closest Andean populations. Implications for the conservation of coastal populations and their value for the conservation of the family are discussed.

\section{MATERIAL AND METHODS}

During surveys conducted between 2014 and 2019 in coastal basins near the city of Concepción, four individuals of the catfish genus Diplomystes were recorded in Laraquete $(n=2)$ and Carampangue $(n=2)$ (Figs. 1-2; Tab. 1). These fish were collected using a HT-2000 Battery Backpack electrofisher (Halltech Aquatic Research Inc.) and anesthetized with BZ-20 (in a solution of $1 \mathrm{~mL}$ in $5 \mathrm{~L}$ of water) for further procesing. Physical parameters like water velocity, dissolved oxygen, temperature, and turbidity were measured with a Multiparameter (HANNA Instruments). Two complete specimens, one from each basin, were preserved in $95 \%$ ethanol, whereas the other two were released in situ. For one of the released specimens (Laraquete), a small piece 
of the adipose fin was carefully removed and preserved in $95 \%$ ethanol. In total, three samples were available for molecular analyses. Preserved specimens are stored in the fish collection of the Instituto de Ciencias Marinas y Limnológicas, Universidad Austral de Chile (see Tab. 1 for voucher codes).

To determine the phylogenetic relation of the coastal populations with other Andean populations and species, we obtained molecular data, conducted Bayesian phylogenetic analysis and estimated a haplotype network. Genomic DNA was extracted with the Qiagen DNeasy Blood \& Tissue kit (Qiagen Inc.), following the

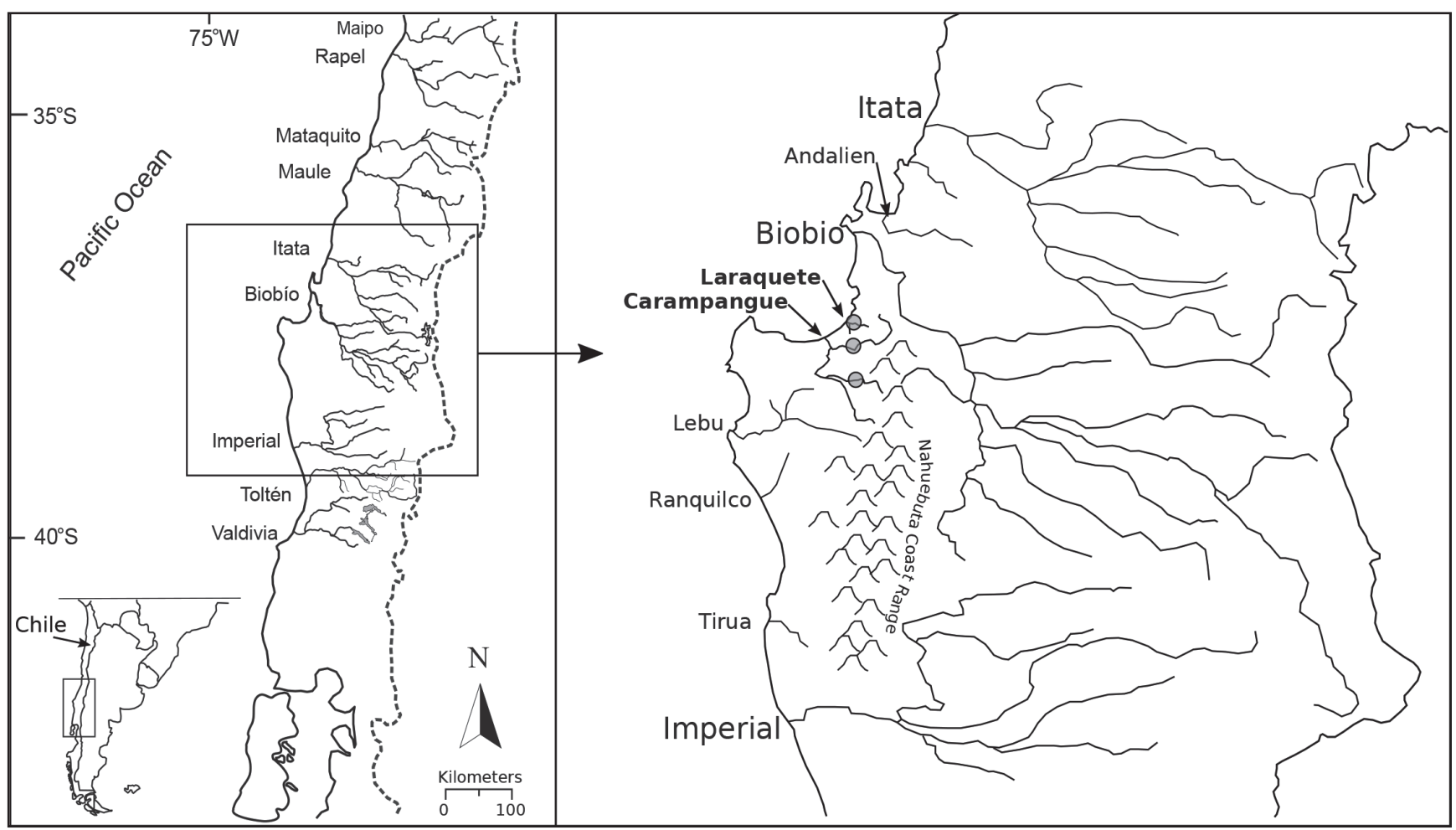

FIGURE 1 I General area and coastal basins where the new specimens of Diplomystes were recorded. Coastal basin names are shown with a smaller font size in the map on the right. The Carampangue and Laraquete basins, from where the samples were collected, are indicated with their names in bold.

TABLE 1 I Sampling details for the specimens of Diplomystes recorded in this study.

\begin{tabular}{|r|c|c|c|c|c|c|}
\hline Specimen Code & Basin & Site & Latitude & Longitude & Collection date & Comment \\
\hline Lar01 & Laraquete & Las Cruces River & -37.1631 & -73.1667 & $18-04-2019$ \\
Complete juvenile \\
preserved
\end{tabular}


manufacturer's protocol and two mitochondrial DNA fragments were amplified, the gene Cytochrome b (Cytb) and the Control Region (CR). The gene Cytb was amplified using the primers Glu31 (5'-TGRCTTGAAAAACCACCGTTGT-3') and Cat.Thr29 (5'-ACCTTCGATCTCCTGATTACAAGA-3') (Unmack et al., 2009), whereas the CR was amplified with primers L-PRO (5' AACTCTCACCCCTAGCTCCCAAAG 3') and Phe27R (5' TAGGGTTCGTCTTAACATCTTCAGTG 3') (Meyer et al., 1994), with final concentrations for PCR components per $25 \mu \mathrm{L}$ reaction as follows: $25 \mathrm{ng}$ template DNA, $0.25 \mu \mathrm{M}$ of each primer, 0.625 units of GoTaq DNA polymerase (Promega, Madison, WI, USA), $0.1 \mathrm{mM}$ of each dNTP, $2.5 \mu \mathrm{L}$ of 10 reaction buffer and $2.5 \mathrm{mM} \mathrm{MgCl} 2$. Amplification parameters were as follows: $95{ }^{\circ} \mathrm{C}$ for $2 \mathrm{~min}$ followed by 35 cycles of $95{ }^{\circ} \mathrm{C}$ for $30 \mathrm{~s}, 48{ }^{\circ} \mathrm{C}$ for $30 \mathrm{~s}$, and $72{ }^{\circ} \mathrm{C}$ for $90 \mathrm{~s}$, and $72{ }^{\circ} \mathrm{C}$ for 7 min. Purification and sequencing was conducted at MACROGEN Inc. (South Korea). Chromatograms were edited in CodonCode Aligner 8.0.2 (Dedham, MA, USA). Sequences were edited with the software BioEdit 7.0.5.2 (Hall, 1999), aligned using ClustalW (available in Bioedit) with default parameters, and checked by eye. These new generated sequences (GenBank acc. MN640585-MN640590) were combined for further analyses with a subset of available sequences from Muñoz-Ramírez et al. (2014) that includes all currently known species from Chile (D. incognitus, D. nahuelbutaensis, D. camposensis; except the presumably extinct D. chilensis), and Argentina (D. cuyanus, D. viedmensis, and D. mesembrinus) (GenBank acc. numbers JX648663-JX649064).

Phylogenetic relationships were reconstructed by Bayesian inference using MrBayes 3.1.2 (Ronquist, Huelsenbeck, 2003) following the methodology described in Muñoz-Ramírez et al. (2014). We included each mitochondrial region (Cytb and $\mathrm{CR}$ ) as separate partitions in the Bayesian analysis. The substitution model obtained by jModelTest version 0.1.1 (Posada, 2008) for Cytb and CR was HKY + I, and GTR $+\mathrm{I}+\mathrm{G}$, respectively. We conducted two independent runs of 5,000,000 generations sampling every 1000 trees to check for convergence in the estimated parameters. The initial $10 \%$ of the resulting trees was discarded as burn-in using the 'sumt' command. Once convergence of the two independent runs was confirmed, parameter estimates from both runs were combined to obtain a total of 9002 trees. A 50\% majority-rule consensus tree with branch lengths was reported. Subsequently, to examine genetic structure between coastal populations and the closest related populations (based on the tree), we constructed a haplotype network using the median joining algorithm developed by Bandelt et al. (1999) and implemented in the software PopART (Leigh, Bryant, 2015).

Due to the low sampling size in coastal rivers, a randomization test was conducted to statistically evaluate differences between the coastal rivers and the Biobío River accounting by the differences in sampling size. In this test, the level of genetic structure $\left(F_{\mathrm{s}}\right)$ between coastal and Biobío populations was compared with a null distribution of 10,000 random $F_{\text {st }}$ values, assuming a panmmictic population model. Each random $F_{\text {st }}$ value was obtained by sampling three individuals from the total pool of samples (coastal and Biobío samples) and then calculating the $F_{\text {st }}$ value between these three samples and the remaining samples. All these calculations were conducted in R (R Core Team, 2017). 


\section{RESULTS}

All four specimens captured were juveniles with sizes between 3.9 and $7.5 \mathrm{~cm}$ (Figs. 2AC). The habitat in all the sites was relatively similar, but quantitative data was available only for the Lia River. This site was characterized by well oxygenated $\left(7.47 \mathrm{mgL}^{-1}\right)$, medium-speed flowing water (mean water velocity and mean discharge recorded were $1.05 \mathrm{~ms}^{-1}$ and $7.62 \mathrm{~m}^{3} \mathrm{~s}^{-1}$, respectively) with substrate dominated by pebbles and boulders and abundant native vegetation along the riversides (Fig. 2D). The mean depth of the river was $0.43 \mathrm{~m}$, the mean river width was $22 \mathrm{~m}$, and mean water temperature was $16.5{ }^{\circ} \mathrm{C}$.

Based on the molecular results (Fig. 3A), the individuals found in Laraquete and Carampangue basins were closely related to the populations present in the Andean Biobío Basin, indicating these coastal populations belong to the lineage of Diplomystes

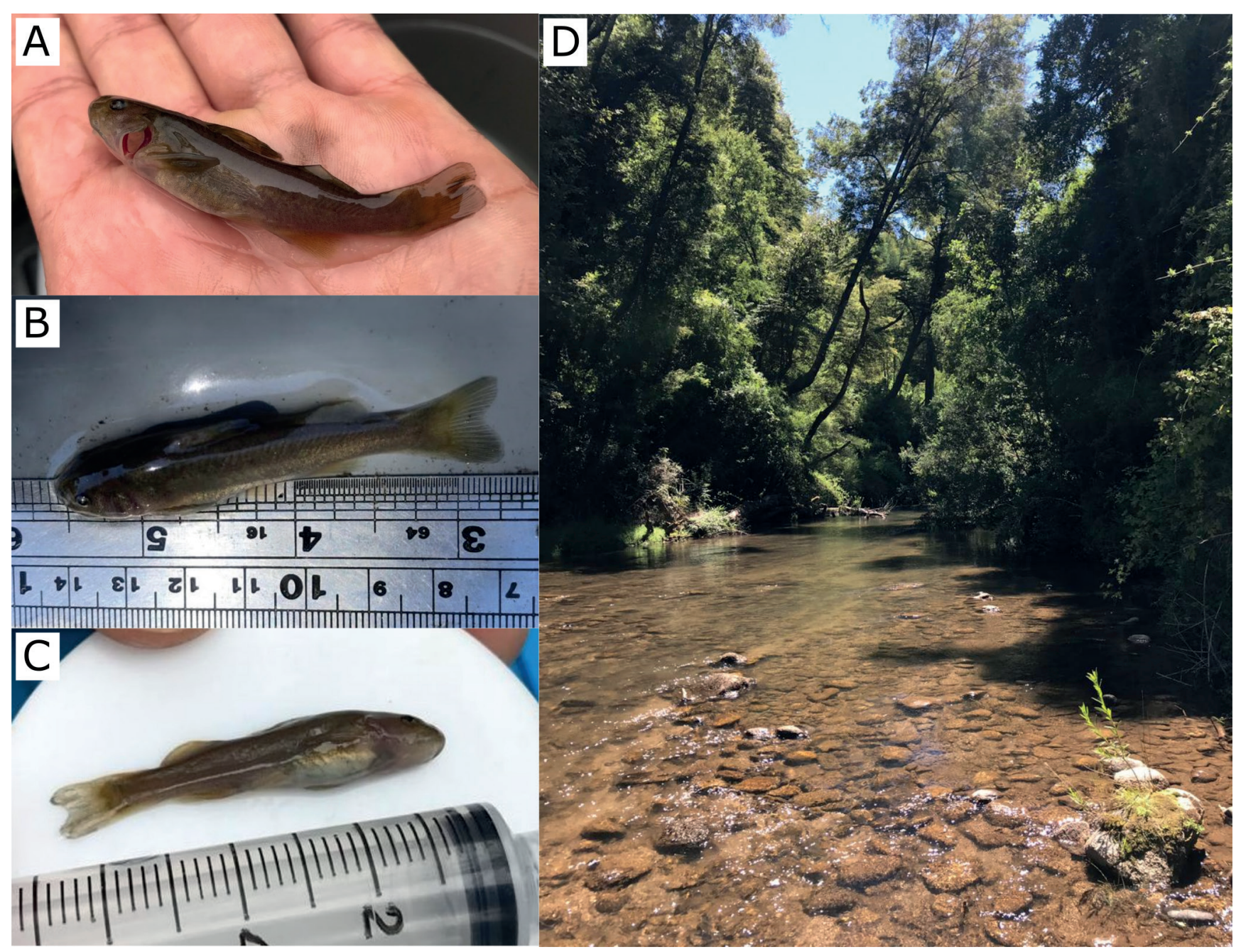

FIGURE 2 I Individuals of Diplomystes nahuelbutaensis recorded in this study and their habitat. A. individual collected in Laraquete (Laro1); B. individual collected and released in Carampangue. C. individual collected in Laraquete (Laro2) and released; D. Habitat of $D$. nahuelbutaensis in the Cabrera River, Carampangue Basin. 
nahuelbutaensis present in the Biobío River. Nevertheless, and despite their genetic proximity with the Biobío populations, the haplotype network shows these coastal populations represent a separate genetic group, with haplotypes not shared with any previously analyzed Biobío populations (Fig. 3B). This result was confirmed by the randomization test (Fig. 4) which shows that the genetic differentiation between the coastal and Biobío samples was significantly larger than chance, as shown by the comparison of the $F_{\text {st }}$ value relative to the null distribution of $F_{\text {st }}$ values expected under a panmictic population model. This supports the separation of these coastal populations from the Biobío Basin and rules out the possibility of a recent translocation.

\section{DISCUSSION}

The only previous reference of Diplomystes from a coastal basin is provided by early material collected in the Andalién Basin by Eigenmann in 1919, studied later by several authors (e.g., Arratia, 1987; Arratia, Quezada-Romegialli, 2017). Unfortunately, more recent studies on the Andalién Basin (Ruiz, 1993; Habit, Victoriano, 2005), which

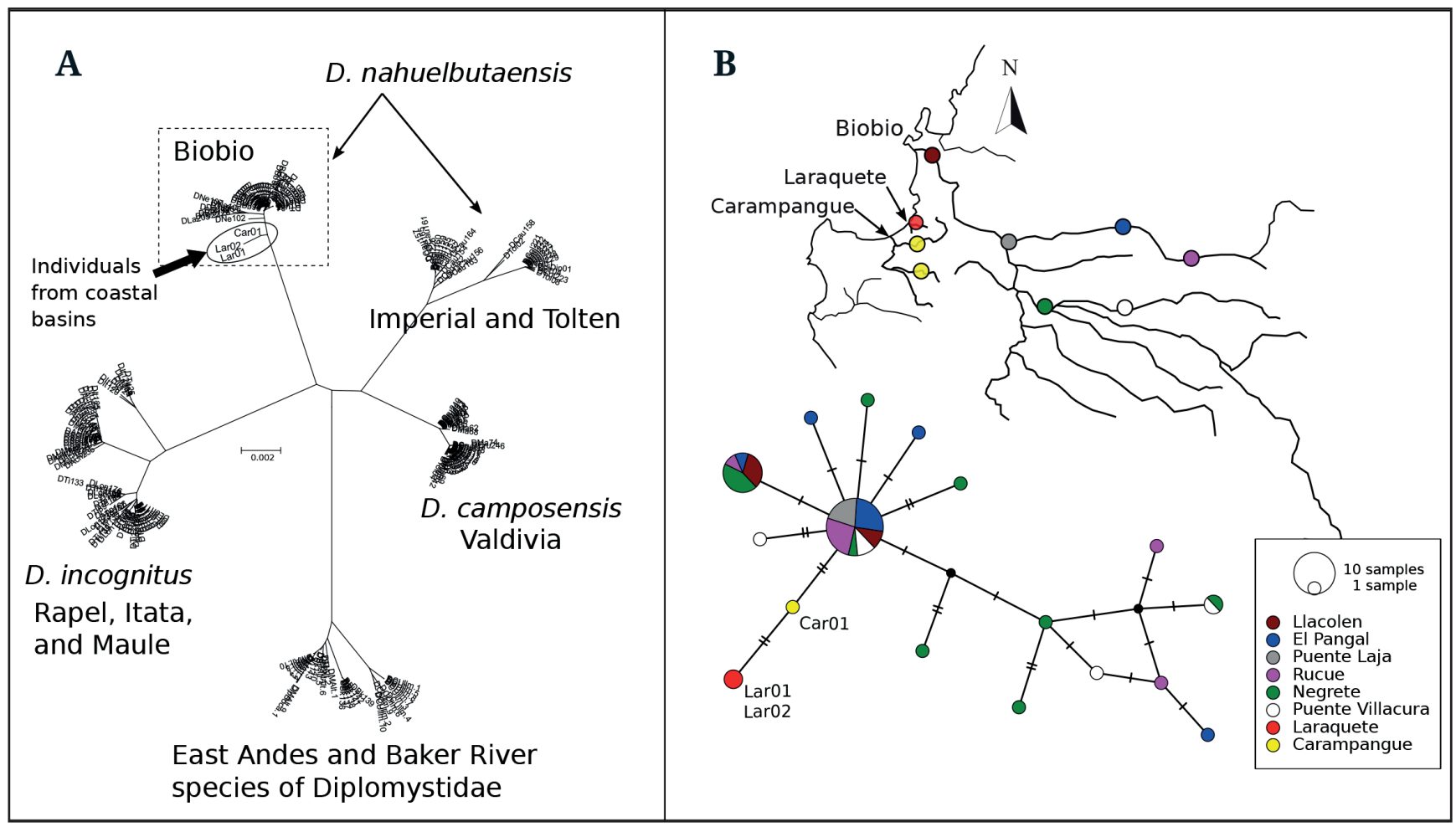

FIGURE 3 I Phylogenetic position of the Coastal populations of Diplomystes recorded in this study in relation to the diversity of the family presented in Muñoz-Ramírez et al. (2014), inferred from the analyzes of two mitochondrial DNA regions (Cytochrome b and Control Region). A. Unrooted Bayesian phylogenetic tree. B. Haplotype network for Diplomystes including samples from the Biobío Basin (from Muñoz-Ramírez et al., 2014) and the individuals sampled in this study. The size of the haplotype represents its frequency, whereas the color represents its geographic distribution. Dashes on lines connecting two haplotypes represent either mutational steps or uncollected haplotypes. 


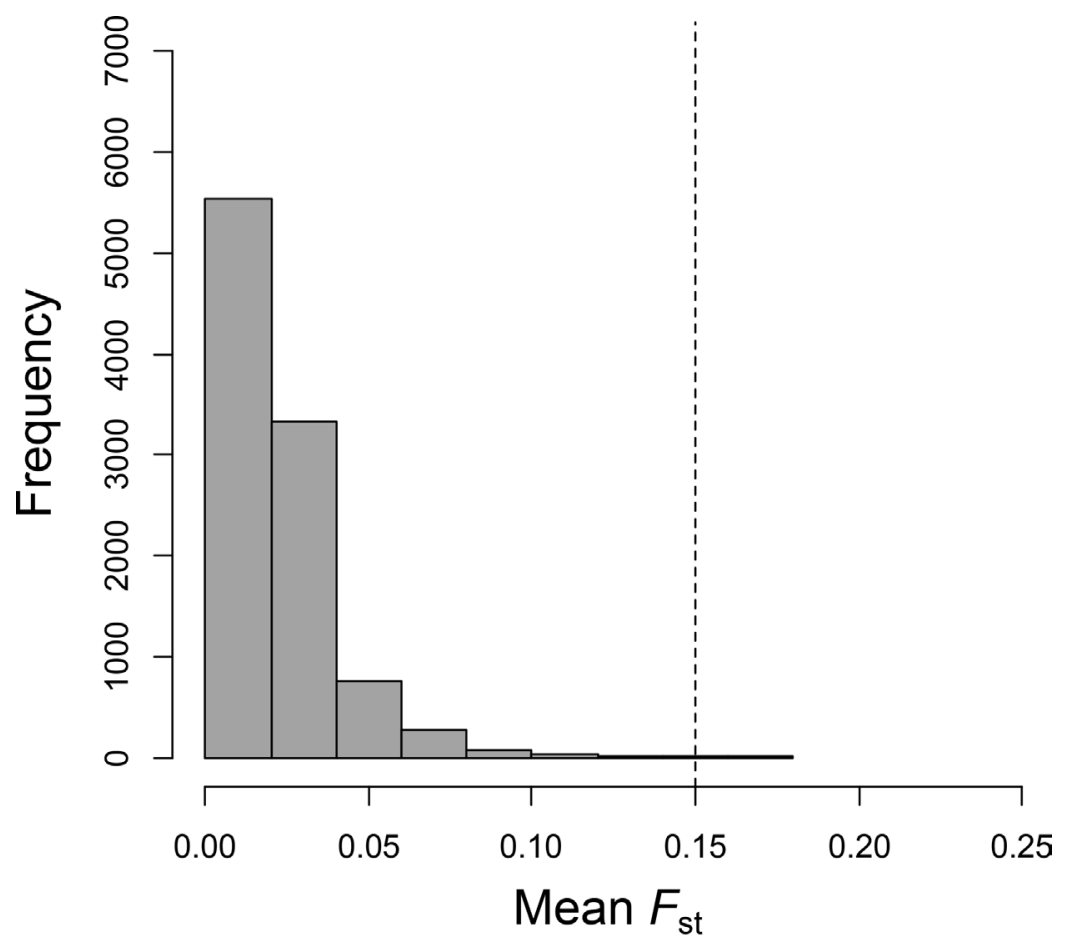

FIGURE 4 I Null distribution of Fst values assuming a panmictic model versus the observed Fst value (vertical line) between Coastal and Biobío samples of Diplomystes nahuelbutaensis.

have surveyed the basin during multiple years, have resulted in unsuccessful attempts to sample new individuals. These authors have therefore suggested the local extinction of D. nahuelbutaensis in the Andalién Basin. The present study, therefore, represent the rediscovery of diplomystids from coastal basins after a century (since 1919) and first records in the Laraquete and Carampangue basins.

Implications for conservation. Based on evidence of high mobility provided by genetics (e.g., Muñoz-Ramírez et al., 2015, 2016) and radio telemetry (Oyanedel et al., 2018), it has been suggested that diplomystids require large river networks to meet their ecological demands and that this factor could explain their absence in small river basins. Conservation efforts, therefore, were assumed challenging because the high mobility and large home range of diplomystids would imply the protection of large and well connected river networks. The present record of Diplomystes in coastal basins changes this view because it shows that the extent of the habitat is not an impediment for long term survival and suggests that other factors, such as habitat quality and/or resource availability, may play a more important role for Diplomystes survival. Therefore, preserving good quality habitats seems fundamental (Beltrán-Concha et al., 2012). Understanding the basis for population survival in small basins will provide important insights for the conservation of Diplomystes in Andean Basins, where the protection of small, suitable river sections rather than large river networks seems more feasible (Díaz et al., 2019).

Unfortunately, coastal basins have also experienced high levels of anthropogenic activities and are under high environmental pressure due to land use changes from 
native forest to exotic tree plantations and agricultural lands (Fierro et al., 2017). Land use change is the leading cause of impaired biodiversity in freshwater environments, and recently, it has been listed as the top threat to fauna and flora in Chilean streams (Fierro et al., 2019). For instance, deforestation in south-central Chile has reached $4.1 \%$ of annual loss of native forests to exotic species plantations during last decades (Altamirano, Lara, 2010), and timber plantations have grown ten-fold between 1990 and 2007 (Nahuelhual et al., 2012). Another significant driver of biodiversity loss in Chile is the introduction of exotic fish (principally salmonids), which negatively impacts native fish populations by predation and competition for food and space (Elgueta et al., 2013; Ortiz-Sandoval et al., 2017). Therefore, it is urgent to increase research efforts and ensure collaboration of all stakeholders of the coastal basins to develop appropriate management plans to preserve this ancient species in these increasingly deteriorated habitats. Periodical surveys in coastal rivers will provide a more comprehensive view of the spatial and temporal distribution of these populations, while population genetic studies will provide a more accurate picture about patterns of gene flow between and within rivers. This will help identifying management units and areas that can be prioritized for conservation.

Conservation status for coastal populations. Diplomystes from coastal basins occupy very small distribution areas. The area of the Carampangue Basin and the Laraquete Basin are $1262 \mathrm{~km}^{2}$ and $110 \mathrm{~km}^{2}$, respectively (Molina, 2014). However, if only the area occupied by water (lakes, rivers, and tributaries) is considered, the occupied area is rather small. For example, the maximum area that can be potentially occupied by the fish in the Carampangue River and its tributaries was estimated to be $5.45 \mathrm{~km}^{2}$. This area was calculated by multiplying the estimated length of the river network $(272.59 \mathrm{~km})$ and an average river width of $20 \mathrm{~m}$. Note that this value is still an overestimation of the area that can be actually occupied by the fish as it does not account for areas of the river network that are unsuitable for the species. In addition, life-history traits reported for diplomystids in other basins indicate low fecundity (Vila et al., 1996) and low densities (Habit et al., 2009), which may augment the level of threat on these coastal populations assuming these coastal populations present similar life-history traits. Following the criteria described by the International Union for Conservation of Nature (IUCN 2019) and based on the very small area of occupancy of coastalbasin populations, their isolation from other basins, the evidence of low fecundity and density (from close relatives), and the increasing environmental impacts in their area of distribution, populations from the Carampangue and Laraquete basins can be classified as Critically Endangered (CE).

The finding of Diplomystes in coastal basins reveals how little is known about the biodiversity of these ecosystems and the need for adequate surveys and monitoring. Excluding coastal basins from broader biodiversity analyses may bias the knowledge of patterns and processes that are relevant to regional biodiversity. Habit, Victoriano (2005) stated that there is no distinct fish assemblage for coastal river basins as they may share all the species with Andean basins. Although this might be true, the little information about coastal communities should preclude categorical claims. Indeed, the finding of new populations of genetically differentiated Diplomystes suggests that these basins could be valuable for biodiversity and conservation. Until more surveys 
are rigorously conducted in coastal systems, the knowledge about the biodiversity of Chilean and Neotropical freshwater communities will remain incomplete.

The finding of Diplomystes in coastal river basins is relevant because it shows that their populations can survive and persist in small river networks and suggests that local habitat conditions may play a more important role in their population persistence than the size of the basin. It is key to monitor these populations and explore these and nearby basins thoroughly to estimate the actual distribution of Diplomystes in coastal river basins and assess their conservation status. Lessons from future research on these populations will be valuable for the conservation of a family that greatly enriches the diversity of catfishes worldwide.

\section{ACKNOWLEDGMENTS}

We thank Francisco Silva for his help in the lab and Maribel Beltrán for her help in the field. This study was supported by FONDECYT Postdoctoral 3180331 (CM-R), FONDECYT 11180545 (KG), and BIOFOREST-Arauco S.A.

\section{REFERENCES}

- Altamirano A, Lara A. Deforestación en ecosistemas templados de la precordillera andina del centro-sur de Chile. Bosque. 2010; 31(1):53-64. http://dx.doi.org/10.4067/S071792002010000100007

- Arratia G. Preferencias de habitat de peces siluriformes de aguas continentales de Chile (Fam. Diplomystidae y Trichomycteridae). Stud Neotrop Fauna E. 1983; 18(4):217-37. https://doi. org/10.1080/01650528309360637

- Arratia G. Description of the primitive family Diplomystidae (Siluriformes, Teleostei, Pisces): Morphology, taxonomy, and phylogenetic implications. Bonner Zoologische Monographien. 1987; 24:1120.

- Arratia G, Quezada-Romegialli C. Understanding morphological variability in a taxonomic context in Chilean diplomystids (Teleostei: Siluriformes), including the description of a new species. PeerJ. 2017; 5:e2991. http://dx.doi. org/10.7717/peerj.2991

- Bandelt H, Forster P, Röhl A. Medianjoining networks for inferring intraspecific phylogenies. Mol Biol Evol. 1999; 16(1):37-48. http://dx.doi.org/10.1093/ oxfordjournals.molbev.a026036
- Bello MT, Ubeda CA. Estado de conservación de los peces de agua dulce de la Patagonia Argentina. Aplicación de una metodología objetiva. Gayana Zool. 1998; 62(1):45-60.

- Beltrán-Concha M, Muñoz-Ramírez C, Ibarra J, Habit E. Análisis de la dieta de Diplomystes (Siluriformes: Diplomystidae) de Chile. Gayana. 2012; 76(2):102-11. http://dx.doi.org/10.4067/S071765382012000300003

- Díaz G, Arriagada P, Górski K, Link O, Karelovic B, Gonzalez J, Habit E. Fragmentation of Chilean Andean rivers: expected effects of hydropower development. Revista Chilena de Historia Natural. 2019; 92:1. http://dx.doi. org/10.1186/s40693-019-0081-5

- Diogo R. Morphological evolution, adaptations, homoplasies, constraints and evolutionary trends. Catfishes as a case study on general phylogeny and macroevolution. CRC Press; 2004.

- Elgueta A, González J, Ruzzante DE, Walde SJ, Habit E. Trophic interference by Salmo trutta on Aplochiton zebra and Aplochiton taeniatus in southern Patagonian lakes. J Fish Biol. 2013; 82(2):430-43. http://dx.doi.org/10.1111/ j.1095-8649.2012.03489.x 
- Faith DP. Conservation evaluation and phylogenetic diversity. Biol Conserv. 1992; 61(1):1-10. https://doi.org/10.1016/00063207(92)91201-3

- Fierro P, Bertrán C, Tapia J, Hauenstein E, Peña-Cortés F, Vergara C, Cerna C, Vargas-Chacoff L. Effects of local land-use on riparian vegetation, water quality, and the functional organization of macroinvertebrate assemblages. Sci Total Environ. 2017; 609:724-34. https://doi. org/10.1016/j.scitotenv.2017.07.197

- Fierro P, Valdovinos C, Arismendi I, Díaz G, Ruiz De Gamboa M, Arriagada L. Assessment of anthropogenic threats to Chilean Mediterranean freshwater ecosystems: Literature review and expert opinions. Environ Impact Assess Rev. 2019; 77:114-21. https://doi.org/10.1016/j. eiar.2019.02.010

- Grande L. Redescription of Hypsidoris farsonensis (Teleostei: Siluriformes), with a reassessment of its phylogenetic relationships. J Vert Paleont. 1987; 7(1):2454. https://doi.org/10.1080/02724634.1987. 10011636

- Habit E, Jara A, Colin N, Oyanedel A, Victoriano P, González J et al. Threatened fishes of the world: Diplomystes camposensis Arratia, 1987 (Diplomystidae). Environ Biol Fishes. 2009; 84(4):393-94. https://doi.org/10.1007/s10641-008-9434-7

- Habit E, Victoriano P. Peces de agua dulce de la Cordillera de la Costa. In: SmithRamírez C, Armesto J, Valdovinos C, editors. Historia, biodiversidad y ecología de la Cordillera de la Costa de Chile. Santiago: Editorial Universitaria; 2005. p.392-406.

- Hall TA. BioEdit: a user-friendly biological sequence alignment editor and analysis program for Windows 95/98/NT. Nucleic Acid S. 1999; 41:95-98.

- Hardman M. The phylogenetic relationships among non-diplomystid catfishes as inferred from mitochondrial cytochrome b sequences; the search for the ictalurid sister taxon (Otophysi: Siluriformes). Mol Phyl Evol. 2005; 37(3):700-20. https://doi. org/10.1016/j.ympev.2005.04.029

- International Union for Conservation of Nature (IUCN). Standards and petitions subcommittee. Guidelines for using the IUCN Red List categories and criteria. Version 14 [Internet]. 2017. Available from: https://www.iucnredlist.org/resources/ redlistguidelines
- Leigh JW, Bryant D. PopART: Fullfeature software for haplotype network construction. Method Ecol Evol. 2015; 6(9):1110-16. https://doi.org/10.1111/2041210X.12410

- López HL, Morgan CC, Montenegro MJ. Ichthyological ecoregions of Argentina. Buenos Aires: ProBiota; 2002.

- Lundberg JG, Baskin JN. The caudal skeleton of catfishes, order Siluriformes. Am Mus Novit. 1969; 2398:1-49.

- Meyer A, Morrissey JM, Schartl M. Recurrent origin of a sexually selected trait in Xiphophorus fishes inferred from a molecular phylogeny. Nature. 1994; 368(6471):539-42. https://doi. org/10.1038/368539a0

- Ministerio Secretaria General De La Presidencia (MINSEGPRES). Aprueba y oficializa nómina para el tercer proceso de clasificación de especies según su estado de conservación [Internet]. Santiago, 2008, Available from: http://www.leychile. $\mathrm{cl} / \mathrm{N}$ ? $\mathrm{i}=273235 \& \mathrm{f}=2008-06-30 \& \mathrm{p}=$

- Molina GT. Inventario de Cuencas, Subcuencas, y Subsubcuencas de Chile [Internet]. Santiago: Ministerio De Obras Públicas (MOP); 2014. Available from: http://documentos.dga.cl/CUH5690.pdf

- Muñoz-Ramírez CP, Habit E, Unmack PJ, Johnson JB, Victoriano P. Low Genetic diversity in Diplomystes camposensis, an endemic and endangered catfish from South Chile. Zool Stud. 2016; 55:e16. https:// doi.org/10.6620/ZS.2016.55-16

- Muñoz-Ramírez C, Jara-Flores A, BeltranConcha M, Zuñiga-Reinoso A, Victoriano P, Habit E. Distribución de la familia Diplomystidae (Pisces: Siluriformes) en Chile: nuevos registros. Boletín de Biodiversidad de Chile. 2010; 4:6-17.

- Muñoz-Ramírez CP, Unmack PJ, Habit E, Johnson JB, Cussac VE, Victoriano P. Phylogeography of the ancient catfish family Diplomystidae: Biogeographic, systematic, and conservation implications. Mol Phyl Evol. 2014; 73:146-60. https://doi. org/10.1016/j.ympev.2014.01.015

- Muñoz-Ramírez CP, Victoriano PF, Habit E. Inter-basin dispersal through irrigation canals explains low genetic structure in Diplomystes $c f$. chilensis, an endangered freshwater catfish from Central Chile. Limnologica. 2015; 53:10-16. https://doi. org/10.1016/j.limno.2015.04.004 
- Nahuelhual L, Carmona A, Lara A, Echeverría C, González ME. Land-cover change to forest plantations: Proximate causes and implications for the landscape in south-central Chile. Landscape Urban Plan. 2012; 107(1):12-20. https://doi. org/10.1016/j.landurbplan.2012.04.006

- Ortiz-Sandoval J, Górski K, Sobenes C, González J, Manosalva A, Elgueta A, Habit E. Invasive trout affect trophic ecology of Galaxias platei in Patagonian lakes. Hydrobiologia. 2017; 790(1):201-12. https://doi.org/10.1007/s10750-016-3030-1

- Oyanedel A, Habit E, Belk MC, Solis-Lufí K, Colin N, Gonzalez J, Jara A, MuñozRamírez CP. Movement patterns and home range in Diplomystes camposensis (Siluriformes: Diplomystidae), an endemic and threatened species from Chile. Neotrop Ichthyol. 2018; 16(1):e170134. https://doi.org/10.1590/1982-0224-20170134

- de Pinna MCCD. Phylogenetic relationships of Neotropical siluriforms (Teleostei: Ostariophysi): historical overview and synthesis of hypotheses. In: Malabarba LR, Reis RE, Vari RP, Lucena ZM, Lucena CAS, editors. Phylogeny and classification of neotropical fishes. Porto Alegre: Edipucrs; 1998. p.279-330.

- Posada D. 2008. jModelTest: phylogenetic model averaging. Mol Biol Evol. 2008; 25(7):1253-56. https://doi.org/10.1093/ molbev/msn083

- R Core Team. R: A language and environment for statistical computing. R Foundation for Statistical Computing. Vienna: Austria; 2017. Available from: http://www.R-project.org

- Rivera-Rivera CJ, Montoya-Burgos JI. Back to the roots: Reducing evolutionary rate heterogeneity among sequences gives support for the early morphological hypothesis of the root of Siluriformes (Teleostei: Ostariophysi). Mol Phylogenet Evol. 2018; 127:272-79. https://doi. org/10.1016/j.ympev.2018.06.004
- Ronquist F, Huelsenbeck JP. MrBayes 3: Bayesian phylogenetic inference under mixed models. Bioinformatics. 2003; 19(12):1572-74. https://doi.org/10.1093/ bioinformatics/btg180

- Ruiz VH. Ictiofauna del río Andalién (Concepción, Chile). Gayana Zool. 1993; 57:109-278.

- Ruzzante DE, Walde SJ, Cussac VE, Dalebout ML, Seibert J, Ortubay S, Habit E. Phylogeography of the Percichthyidae (Pisces) in Patagonia: roles of orogeny, glaciation, and volcanism. Mol Ecol. 2006; 15(10):2949-68. https://doi.org/10.1111/ j.1365-294X.2006.03010.x

- Sullivan JP, Lundberg JG, Hardman M. A phylogenetic analysis of the major groups of catfishes (Teleostei: Siluriformes) using rag1 and rag2 nuclear gene sequences. Mol Phylogenet Evol. 2006; 41(3):636-62. https://doi.org/10.1016/j.ympev.2006.05.044

- Vila I, Contreras M, Fuentes L. Reproducción de Diplomystes nahuelbutaensis Arratia 1987 (Pises: Diplomystidae). Gayana Oceanol. 1996; 4:129-37.

- Unmack PJ, Bennin AP, Habit EM, Victoriano PF, Johnson JB. Impact of ocean barriers, topography, and glaciation on the phylogeography of the catfish Trichomycterus areolatus (Teleostei: Trichomycteridae) in Chile. Biol J Linn Soc. 2009; 97(4):876-92. https://doi.org/10.1111/ j.1095-8312.2009.01224.x

\section{AUTHOR CONTRIBUTIONS}

Carlos P. Muñoz-Ramírez: Conceptualization, Data curation, Formal Analysis, Funding acquisition, Investigation, Methodology, Project administration, Writing (original draft), Writing (review \& editing). Raul Briones: Funding acquisition, Investigation, Visualization.

Nicole Colin: Conceptualization, Funding acquisition, Investigation, Methodology, Writing (review \& editing).

Pablo Fierro: Data curation, Investigation, Methodology, Writing (review \& editing). 


\section{Neotropical Ichthyology}

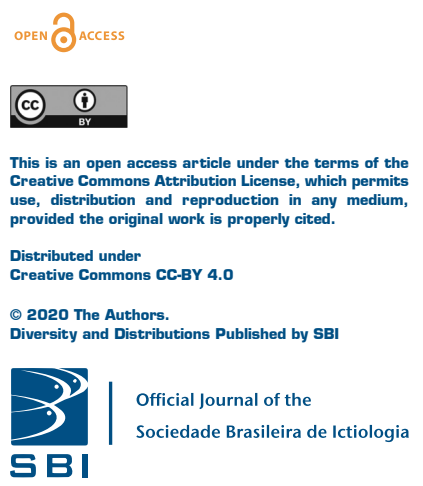

Konrad Górski: Conceptualization, Formal Analysis, Funding acquisition, Investigation, Project administration, Resources, Writing (review \& editing).

Alfonso Jara: Conceptualization, Data curation, Funding acquisition, Investigation, Methodology, Writing (review \& editing).

Aliro Manosalva: Data curation, Methodology.

\section{ETHICAL STATEMENT}

Fish were collected under the Fishing License "Rex 4060 SUBPESCA", provided by the Subsecretariat of Fisheries and Aquaculture of the Ministry of Economy, Promotion and Tourism of Chile.

\section{COMPETING INTERESTS}

Not applicable.

\section{HOW TO CITE THIS ARTICLE}

- Muñoz-Ramírez CP, Briones R, Colin N, Fierro P, Górski K, Jara A, Manosalva A. A Century after! Rediscovery of the ancient catfish Diplomystes Bleeker 1858 (Siluriformes: Diplomystidae) in coastal river basins of Chile and its implications for conservation. Neotrop Ichthyol. 2020; 18(1):e190073. https://doi.org/10.1590/1982-0224-2019-0073 
